\title{
A PORTRAIT OF SUNDANESE MAINTENANCE IN MULTILINGUAL LEARNING IN BOGOR
}

\author{
Krishandini, Defina and Endang Sri Wahyuni \\ Bogor Agricultural University \\ email:krishandini@yahoo.com
}

\begin{abstract}
Elementary pupils who used to be multilingual speakers began to change into monolingual. Giving Indonesian language as a language of unity to the elementary students does not mean hoping regional languages to become extinct, especially with the Sundanese language which is the top five in the number of speakers in Indonesia. Therefore, the researchers conducted research in several schools in Bogor with the aim of 1) knowing the level of institutional and government support in maintaining the use of Sundanese language in Bogor; 2) knowing the implementation of Sundanese language learning in Bogor; 3) knowing the process of multilingual learning. A quantitative method was used by distributing questionnaires to several primary schools in Bogor with a total of 47 teachers and doing observations of elementary students. Findings indicate that negative attitudes toward the Sundanese language are shown by elementary students with occasional use of Sundanese language in interacting with their friends. Institutions and governments are less supportive by not requiring each elementary to have a special Sundanese-speaking day school within a week and not allowing teachers to improve their abilities. The ability of Sundanese language teachers in elementary schools in Bogor is still low in scientific writing using Sundanese language.
\end{abstract}

Keywords: Sundanese language, language maintenance, multilingual learning

\section{POTRET PELESTARIAN BAHASA SUNDA DALAM PENBELAJARAN MULTI-BAHASA DI BOGOR}

\begin{abstract}
Abstrak
Siswa sekolah dasar yang dulunya bermulti-bahasa sudah mulai berbahasa tunggal. Penetapan bahasa Indonesia sebagai bahasa persatuan tidak harus mematikan bahasa daerah, termasuk bahasa Sunda yang memiliki jumlah pembicara terbesar ke lima di Indonesia. Peneliti melakukan penelitian dengan tujuan 1) mengetahui tingkat dukungan lembaga dan pemerintah dalam pelestarian bahasa Sunda di Bogor; 2) mengetahui pelaksanaan pembelajaran bahasa Sunda di Bogor; 3) mengetahui proses pembelajaran multi-lingual. Penelitian menggunakan metode kuantitatif dengan membagikan angket ke beberapa sekolah dasar di Bogor dengan total 47 guru dan melakukan observasi terhadap siswa sekolah dasar. Temuan penelitian menunjukkan adanya sikap negatif terhadap bahasa Sunda pada siswa sekolah dasar dengan kadang-kadang menggunakan ba-
\end{abstract}


hasa Sunda ketika berinteraksi dengan teman-temannya. Lembaga dan pemerintah kurang mendukung dengan tidak mewajibkan sekolah dasar untuk menggunakan bahasa Sunda sehari dalam seminggu dan tidak mengusahakan peningkatan guru dalam berbahasa Sunda. Keterampilan guru masih rendah dalam keterampilan menulis ilmiah dalam bahasa Sunda.

Kata kunci: bahasa Sunda, pelestarian bahasa, pembelajaran multibahasa

\section{INTRODUCTION}

The use of Sundanese language in Bogor City, based on observation, began to decline. Children in Bogor City mostly use Indonesian language in their conversation, either with parents or with friends. The fact that Bogor is located near Jakarta, the capital city of Indonesia, may be the reason of this, as more than $40 \%$ of Bogor residents work in Jakarta. Parents working in Jakarta will communicate more in Indonesian language. Children also speak Indonesian language to their parents. Ideally, parents are proud of their children who are multilingual. They can speak in various languages, namely Indonesian, regional languages, and foreign languages. Because of the condition that local language is not a language used at home, schools are hoped to provide local language learning that can encourage students to speak their own local language. Unfortunately, based on observation, Sundanese language is been thought to elementary pupils in Bogor only as a supplementary subject. The pupils are less interested in practicing their local language. Moreover, this situation is worse for children having non-sundanese parents. This condition will make the Sundanese language which is the language of Bogor area, eventually become extinct. Sundanese speakers may hardly be found in Bogor because one of the determinants of language maintenance is the attitude of the speaker community to their language (UNESCO, 2005:2).

To support the sustainability of regional languages, especially sundanese language in Bogor, an active participation of key stakeholders such as parents, communities, schools, and local governments is required. Therefore, it is crucial to revitalize the use of Sundanese language, especially in Bogor area, by establishing learning program in schools whichalso needs to be improved and developed.

Based on the background above, this study aimed to provide answers to the following questions as follow. (1) What is the effort of government of West Java Provincee in preserving Sundanese language? (2) How is the Sundanese language preserved in elementary schools in Bogor? (3) How is the multilingual learning process in elementary schools in Bogor?

In line with the questions above, the following points are the focus of the research. (1) To describe the efforts of government of West Java Province in maintaining Sundanese language. (2) To describe the maintenance of Sundanese lan- 
guage in elementary schools in Bogor. (3) To describe the multilingual learning process in elementary schools in Bogor.

This research is based on two theories namely multilingual concept and the concept of language retention and revitalization which are elaborated below. In KBBI (2003: 762),), being "multilingual" is defined as being able to use more than two languages, or be concerned with more than two languages. In contrast, multilingualism is a feature of a person or a society characterized by the habit of using more than one language. Mackey (Jendra, 2010: 69), says, “... the term multilingual is also sometimes used to refer to the people who can use more than two languages." Furthermore, Jendra (2010:69), at the end of his book which contains sociolinguistic concepts, says, "Multilingualism: is a situation in a speech-community where more than two languages are used."

The ability of a person or society to use more than two languages is not exactly the same as the abilitiy of the native speakers. This is expressed by Wardhaugh (2006:96). "People who are bilingual or multilingual do not necessarily have the same abilities in the language (or varieties); In fact, that kind of parity may be exceptional." Furthermore, Wardhaugh (2006:96) says "A bilingual or multilingual, situation can produce still other effects on one or more of the language involved. As we have just seen, it can lead to loss, e.g., language loss among immigrants...". Sridhar (Wardhaugh, 2006:96) states "Multilingualism involving balanced, nativelike command of all the languages in the repertoire is rather uncommon. Typically, multilinguals have varying degrees of command of the different repertoires. The differences in competence in the various languages might range from command of a few lexical items, formulaic expressions such as greetings, and rudimentary conversational skills all the way to excellent command of the grammar and vocabulary and specialized register and styles." Sridhar stated that language choices are part of the social identity which claims the speakers who must find out the purpose of being socially competented on. Sridhar also adds: 'Multilinguals develop competence in each of the codes to the extent that they need it and for the contexts, which determines language choice, in which each of the languages is used.'

From the above quotations, it can be concluded that multilingualism is the ability of a person in using more than two languages. However, the term "multilingualism" is often thought to be the same as the term "bilingualism," a term used to describe the state of the use of more than one language by individuals, groups or communities (regionally, nationally, internationally). Bilingualism and multilingualism arise from interaction between groups of speakers of a different language. Intercultural language among groups that occurs continuously will produce speakers who can speak more than one language (Beardsmore, 1982:97).

In this era of globalization, it is impossible for languages in this world to survive without the influence of other languages. This increases the number of speakers who master more than one language (at whatever level of their language). People who use more than one 
language in their conversation may be classified as bilingual or multilingual. Thus, there has been amultilingual in communication when one interacts with others.

Language maintenance is related to language shifts that occur in a society. This is in accordance with the opinion of Jendra (2010:144): "Language maintenance is a situation when a speech-community can maintain orcontinue using their language from generation to generation although there are conditions that could affect them to shift to another language."

Meanwhile, Saragih (2012:1-14) reveals that language maintenance is an effort made by speakers or people who are concerned on a language so that the language can fulfill the needs of speakers or those concerned. Sumarsono (Chair \& Agustina, 2010:147) who studied Loloan Malay language in Loloan Village, Nagara City, Bali, said that language can be maintained in the majority of Balinese speakers and it is caused by three factors. First, their residential areas are concentrated in one place geographically separated from the residential areas of Balinese society. Second, there is a tolerance of the majority of Balinese people who want to use Malay Loloan language in communicating with Loloan minority groups. Third, members of the Loloan community have Islamic attitudes that do not accomodate the society, its culture and Balinese language.

In order to prevent the extinction of a language from the community of speakers, language maintenance is maintained. Language maintenance is related and continues with revitalization. Revitaliza- tion is the process of adding vitality to languages that are subject to extinction threats as a result of which language can be re-empowered for the community of its speakers (Grenoble \& Whaley, 2006:12). It is related to motivation and revitalization. This power is concerned with efforts to protect, develop, and coach a language. Revitalization is a process, way, act of reviving or reinforcing (KBBI 2003:954). This means that something that once was lethargic and powerless is re-activated to be more passionate by conducting an activity that is scientific and sustainable.

Research on Sundanese language has been done a lot as well as maintenance of Sundanese language. Silvia (2014: 1-14) studied Sundanese language maintenance in Sarireja Village, Cagak Sub-District, Subang Regency. The resultof the research is there are two factors which may explain maintenance of this language, namely; supporting and inhibiting factors. There are two supporting factors of Sundanese language maintenance in Sarireja Village, Cagak Sub-district Subang Regency, Subang Regency, namely loyalty factor to mother tongue and family environment factor. In contrast, the inhibiting factors are population movement factor, economic factor, and inter-ethnic marriage factor.

Previously, Dasripin (2009: 11) had also conducted research on Sundanese language maintenance on community in Serang District, Banten Province. Dasripin said that the attitude of people in Serang towards Sundanese language is very positive, it can be seen in their daily life.They still use Sundanese language in various situations. Therefore, it is as- 
sumed that the language still survive in the region. However, there is a symptom of language maintenance in multilingual communities. Furthermore, multilingualism in Pangandaran area is quite stable because it does not show any inter-language competition.

From the three studies above, it can be seen that there is a focus on the community. There is an effort to raise the use of Sundanese language among the people. In contrast, this research is more focused on education, especially in elementary schools.

\section{METHODS}

The research used mixed method which combined literature study and field study. Literature study focused on tracing the efforts that have been done by government of West Java Province towards language maintenance. Field study was focused on the condition of Sundanese language maintenance in elementary schools. The population of this research was elementary school teachers in Bogor. The samples of this research were 47 classroom teachers in six elementary schools in Bogor, namely SDN 01 Babakan Dramaga, SD Kebon Pedas 1, SD Muara beres, SD Bogor Baru, SDN Polisi 5, and SDN 02 Pagi Ciluar. In addition, respondents also included 12 English teachers in those six SDs.

Data was collected by giving questionnaires to the respondents and doing interviews. The measurement scale used in the questionnaire was Likert scale according to Sugiyono (2014: 93). This scale can be used to measure attitude, opinion, and perception of a person or group of people about social phenomena.
Descriptive data analysis is intended to present descriptive data by describing the acquisition of data that has been processed, collected, grouped, and analyzed. The collected data regarding the facilities and infrastructure that support the learning of Sundanese, and the level of ability of the Sundanese language teachers are processed, collected, and analyzed to get an overview of learning activities in Sundanese in Bogor.

\section{FINDINGS AND DISCUSSION Findings}

Language maintenance carried out by government of West Java Province based on literature study, government of West Java Province has issued decree of West Java Governor Number 423.5/Kep.674Disdik/2006 about competency standards and basic competence also guideline of curriculum pronunciation level of education unit of Sundanese language and literatureas an effort to maintain Sundanese language (DisdikJabar, 2007).

The following points are set in the decree.

(1) Revoking and declaring that Decision of the Head of Regional Office of the Department of Education and Culture of West Java Province No. 979/102 / Kep / I / 94 on the Local Content of Basic Education Curriculum is not applicable.

(2) Competency standards and basic competence of Sundanese language and literature classes of kindergarten (TK)/raudhatulathfa (RA), elementary/madrasah ibtidaiyah (MI), junior high school (SMP)/madrasah Tsanawiyah (MTs), Senior High School (SMA)/vocational school 
(SMK)/madrasah aliyah (MA) academic year of 2006, consist of: a) competency standardsin curriculum; B) competency standards of Sundanese Language and Literature Subject; C) competencystandardsof graduates of kindergarten/RA, elementary/junior high school, junior high school/senior high school/vocational school.

(3) A description of competency standards and guidelines for the preparation of the curriculum of Sundanese Language and Literature as well as the competency standardsof graduates as it refers to in the second dictum listed in the appendix as an inseparable part of this decision.

(4) Competency standards and basic competence and guidance of curriculum preparation of Sundanese language and literature as well as competency standards of graduates as meant in Second Dictum is a guide in syllabus and assessment. The decree of West Java Governor above was made based on the provincial regulation of West Java No.5 Year 2003 on maintenance of language, literature, and regional literature. This decree is related to the Sundanese language. It states that Sundanese is taught at the level of basic education in West Java. It is in harmony with the provisions of the 1945 Constitution on Education and Culture. Following up the 1945 Constitution, Law No.22 / 1999 on Law No. 20/2003 on National Education System was set.

In addition, the decree also complies with a recommendation from UNESCO in 1999 on the maintenance of mother tongues and government regulation No. $19 / 2005$ on national education standards. Appropriate local contents are given to students starting from SD/MI/ SDLB, SMP/MTs/SMPLB, SMA/ MAN/SMALB, and SMK/MAK as it is stated in Chapter III Clause 7 verse 3-8.

Government's support (central and local) through regulations greatly helps the maintenance of a language. Based on the decree, it can be concluded that there have been efforts from the government of West Java province in Sundanese language maintenance. Sundanese language is the language with the largest number of speakers supported by various parties, both community and government.

Sundanese language maintenance in Bogor. Of the six primary schools studied, all have applied the Governor's Decree of West Java, namely the existence of Sundanese language as a local content. The learning of Sundanese language is done once a week and it is taught by classroom teachers in various durations of time. Of the 47 respondents, $17 \%$ were male and $83 \%$ of them were female. As many as $38.3 \%$ respondents have been teaching for 6-15 years while the others (34\%) have been teaching over 25 years. However, even though the teachers are experienced in teaching, none of them is educated in teaching Sundanese language. Of the 47 respondents, only 18 are native speakers of Sundanese language. The rest are speakers of Indonesian, Javanese, and other regional languages in Indonesia.

From the research results, it was found that language maintenance initiated by the government was poorly sup- 
ported by adequate facilities and infrastructure. The supporting factors are the reasons for the weakness of learning Sundanese language in Bogor. that students already have adequate learning resource facilities. Indeed, the source of student learning can be obtained from various things. A creative teacher will make learning fun even with minimum reference that students should

Table 1. Percentage of Supported Facilities in Learning Sundanese Language

\begin{tabular}{|c|c|c|c|c|c|c|}
\hline No. & Statements & $1(\%)$ & $2(\%)$ & $3(\%)$ & $4(\%)$ & $5(\%)$ \\
\hline & $\begin{array}{l}\text { The numbers of teachers and the needs of Sun- } \\
\text { danese language are balance. }\end{array}$ & 17 & 38 & 2 & 43 & 0 \\
\hline & $\begin{array}{l}\text { Text books for teachers to teach Sundanese lan- } \\
\text { guage are adequate. }\end{array}$ & 4 & 36 & 9 & 45 & 2 \\
\hline & $\begin{array}{l}\text { Text books for students to learn Sundanese lan- } \\
\text { guage are adequate. }\end{array}$ & 4 & 36 & 4 & 6 & 0 \\
\hline & $\begin{array}{l}\text { There is a special day to speak Sundanese lan- } \\
\text { guage at school. }\end{array}$ & 13 & 28 & 6 & 34 & 13 \\
\hline
\end{tabular}

1=strongly disagree; 2 =disagree; $3=$ =fair; $4=$ =agree; $5=$ strongly agree

The numbers of teachers and the needs of Sundanese language teachers are balanced because most of the respondents agreed with statement 1 . In contrast, every school in Bogor City does not have a Sundanese teacher. Based on the results of interview, the teachers of Sundanese language did not graduate from Sundanese language education major. They are appointed to teach Sundanese language because they are able to speak Sundanese language.

The teacher is responsible for the students' success. Teachers as facilitators in learning Sundanese language should have adequate learning resources. They can be in the form of textbooks, dictionaries, magazines, newspapers, and reference books. Adequate learning resources will increase teachers' knowledge. About $45 \%$ of respondents answered that they have obtained adequate learning resources as one of facilities from school. However, $36 \%$ of respondents did not agree use. Teachers should be able to use various learning methods so that students are interested in learning the language. For learning a language, teachers can use classroom learning methods. With the method of learning outside the classroom, teachers (at once) introduce Sundanese culture full of politeness. It needs an agency support to make this happens.

Institutional support for the maintenance of Sundanese language has not been fully visible in every school in Bogor, especially primary schools. This can be seen from the answers given by respondents about the special day for Sundanese language, $34 \%$ of respondents agreed, but $28 \%$ of them did not agree that the institution gives one day special to speak Sundanese language at school. This rule has not been applied in some schools in Bogor so it needs to be a concern for government of Bogor city. If the government gives this special day's rule to every school in Bogor, surely the whole 
school will obey it.

About $36 \%$ of teachers said that the reference is minimum (table 1 ). This may lead to teachers'difficulties in understanding Sundanese language. The lack of reference books reflects the lack of attention given by institution and government to the quality of Sundanese language teachers for elementary students in Bogor. The following table shows the level of awareness of institution/government to Sundanese language teachers for elementary students in Bogor. cussions on the achievement of Sundanese language teaching.

Determining the ability of elementary school teachers in using Sundanese language in Bogor can be done based on the the teachers' origin. About $81 \%$ of elementary school teachers in Bogor are from West Java. Teachers from West Java can be classified as speakers of Sundanese language. The interesting point of the data we get is various regions of sundanese teachers in elementary schools in Bogor. They are from different regions in

Table 2. Persentage of Increasing Quality of Sundanese Language Teachers

\begin{tabular}{|c|c|c|c|c|c|c|}
\hline No. & Statements & $1(\%)$ & $2(\%)$ & $3(\%)$ & $4(\%)$ & $5(\%)$ \\
\hline 1. & $\begin{array}{l}\text { City education authority givesopportunity to Sun- } \\
\text { danes language teachers to join a training. }\end{array}$ & 6 & 45 & 9 & 30 & 6 \\
\hline 2. & School gives opportunity to join a training. & 11 & 34 & 15 & 32 & 4 \\
\hline 3. & $\begin{array}{l}\text { A meeting is held to discuss and solve some prob- } \\
\text { lems in learning process. }\end{array}$ & 9 & 38 & 9 & 34 & 4 \\
\hline 4. & $\begin{array}{l}\text { A meeting is held to discuss and solve some prob- } \\
\text { lems in learning method. }\end{array}$ & 9 & 36 & 9 & 36 & 2 \\
\hline 5. & $\begin{array}{l}\text { A meeting is held to discuss and solve some prob- } \\
\text { lems in teaching achievement. }\end{array}$ & 9 & 26 & 17 & 40 & 0 \\
\hline
\end{tabular}

Notes: $1=$ strongly disagree; $2=$ disagree; $3=$ fair; $4=$ agree; $5=$ strongly agree

About $45 \%$ of respondents expressed their disagreement on statement 1 . This proves the lack of government's attention on Sundanese language teachers, especially in elementary school level. Similarly, 34\% of respondents disagreed on statement 2. Respondents stated that they do not often hold meetings to discuss about problems in learning Sundanese (stated 38\%). They also do not often hold meetings to discuss learning methods (36\%). Meanwhile, $26 \%$ of respondents expressed disagreement over the statement of the often-discussed achievement of teaching, but $40 \%$ of respondents expressed their agreement on frequent dis-
Indonesia, namely, North Sumatra, Central Sulawesi, Central Java, and East Java. Wahya (2011: 1-9) stated that a person is considered capable of speaking sundanese language if the concerned person can use "undakusuk" (speech level) properly.

It needs further research to discuss problems of ability level to comprehend speech level of Sundanese language among teachers from inside and outside West Java. About $40 \%$ of teachers use Indonesian as a colloquial language and $38 \%$ of teachers use Sundanese language, $19 \%$ of teachers use mixed Indonesian and Sundanese language. In fact, about 
$2 \%$ of respondents use Java language in everyday communication. With the varied use of everyday language by Sundanese language teachers, will it affect the level of ability of Sundanese language teachers in teaching Sundanese language at school? This can be seen in the following table.
Respondents also expressed disagreement if they are very fluent in Sundaneselanguage (stated $26 \%$ of respondents). The authors questioned on the respondents' doubts about their ability to speak because $21 \%$ and $17 \%$ of respondents hesitated to answer statement 3 and 4 . The authors assume that there is no test

Table 3. Persentage ofthe Teachers' Ability in Speaking Sundanese Language

\begin{tabular}{|c|c|c|c|c|c|c|}
\hline No. & Statements & $1(\%)$ & $2(\%)$ & $3(\%)$ & $4(\%)$ & $5(\%)$ \\
\hline 1. & Teachers master sundanese language. & 0 & 0 & 15 & 43 & 40 \\
\hline 2. & Teachers understand sundanese language. & 0 & 9 & 0 & 25 & 38 \\
\hline 3. & Teachers master sundanese language in speaking. & 4 & 26 & 21 & 32 & 17 \\
\hline 4. & Teachers can speak sundanese language fluently. & 4 & 15 & 17 & 47 & 17 \\
\hline 5. & Teachers can read sundanese writing fluently. & 2 & 15 & 13 & 55 & 13 \\
\hline 6. & $\begin{array}{l}\text { Teachers can write scientific article in sundanese lan- } \\
\text { guage. }\end{array}$ & 21 & 36 & 11 & 15 & 4 \\
\hline 7. & $\begin{array}{l}\text { Teachers can write simple things in sundanese lan- } \\
\text { guage. }\end{array}$ & 2 & 17 & 21 & 45 & 2 \\
\hline
\end{tabular}

Notes: 1 =strongly disagree; $2=$ disagree; 3 =fair; $4=$ =agree; $5=$ strongly agree

There are four language skills, namely listening, speaking, reading, and writing. These four skills must be possessed if one is declared qualified in mastering one language. Based on table 1 it is known that $43 \%$ of respondents agreed and $40 \%$ of respondents strongly agreed thatSundanese language teachers at the elementary level in Bogor have excellent listening comprehension when others speak Sundanese. This means that everyday language that the respondent uses and the origin of the respondent's area does not affect understanding level of the respondent. However, respondents have varied answers to statements about the fluency of respondents in speaking Sundanese. About $32 \%$ of respondents agreedwith the statement 3 and $47 \%$ of respondents agreed with statement 4 . on Sundaneselanguage to determine the ability level of a person in the language, such as Indonesian language that has UKBI (test proficiency in Indonesian language) so that respondents hesitate in responding the statement. However, it needs to be a concern of institution and government if the ability of Sundanese language teachers in teaching Sundanese for elementary students in Bogor is low because their Sundanese language skills are not comprehensive. The low ability of teachers in mastering the material will affect students. Students' love Sundanese language becomes less well embedded because language learning materials are expected to stimulate students' speaking skill. Pupils are expected to become Sundanese speakers who have a positive attitude toward their language. At the end, 
they have an ability to appreciate and love their language.

Sundanese teachers of elementary school in Bogor have good reading skill. This is stated by $55 \%$ of respondents. However, their writing skills needs to be improved, especially scientific writing. About $36 \%$ of respondents stated that they do not agree to have good scientific writing skills. In contrast, in writing simple things in Sundanese language, $45 \%$ of respondents said they possessed these abilities.

Multilingual learning in primary schools in Bogor, in particular, is not only local and national languages, but also an international language, namely English. This is in accordance with the following quotation. "Multilingualism, rather than monolingualism or even bilingualism, is the reality of most language contexts in our world today. For that reason language program planners and the communities they represent usually want to include educational opportunities that will expand into the national language and perhaps even include an international language" (SIL, 2013).

After it is examined, before the implementation of Curriculum 2013 in 2014, in six elementary schools, students do not only get the subject of Sundanese language, but also subject of Indonesian and English language. These three subjects are given since grade 1 of elementary school. Therefore, students are expected to master these three languages (multilingual). Although, their English skill is still basic, especially English for grade 1 elementary school. Multilingual learning that aims to enable learners to master and use various languages in communication in accordance with the context, turns pupils as learners more dominant using one of the three languages taught. In the classroom, students are more likely to communicate using the Indonesian language, i.e. more than $80 \%$ of them always and very often use Indonesian, when answering questions about Indonesian subjects and other subjects. Even if pupils use Sundanese language, it is more common when they communicate with students who understand Sundanese language. Table 4 shows that only half of total pupils who always speak Indonesian in communication, i.e. $51.2 \%$. The use of Indonesian language in teaching and learning process on Indonesian and other subjects can be seen from the following table.

Unlike subjects of Indonesian and Sundanese language, English subjects are taught by teachers who graduated from English major. They have more than 2 classes. Pupils rarely communicate with English teachers in English. Students also rarely communicate with Sundanese teachers in Sundanese language. They usually communicate in Indonesian language. In using Sundanese language, commonlystudents communicate with their friends who understand Sundanese. The use of English in the process of teaching and learning in the classroom either by pupils or by teachers can be seen from the following table.

Based on the table, pupils never and very rarely communicate with friends using English (stated by 33\% of respondents). Meanwhile, $17 \%$ of respondents stated always communicare with friends 
Table 4. The use of Indonesian Language in Teaching and Learning Process on Indonesian and other Subjects in Class

\begin{tabular}{|c|c|c|c|c|c|c|}
\hline No. & Statements & $1(\%)$ & $2(\%)$ & $3(\%)$ & $4(\%)$ & $5(\%)$ \\
\hline 1. & $\begin{array}{l}\text { Students ask using Indonesian language while they are } \\
\text { learning Indonesian language. }\end{array}$ & 0 & 4 & 17 & 13 & 62 \\
\hline 2. & $\begin{array}{l}\text { Students answer questions using Indonesian language } \\
\text { while they are learning Indonesian language. }\end{array}$ & 0 & 0 & 13 & 9 & 75 \\
\hline 3. & $\begin{array}{l}\text { Students ask using Indonesian language while they are } \\
\text { learning other subjects. }\end{array}$ & 0 & 0 & 11 & 9 & 77 \\
\hline 4. & $\begin{array}{l}\text { Students answer questions using Indonesian language } \\
\text { while they are learning other subjects. }\end{array}$ & 0 & 0 & 13 & 9 & 75 \\
\hline 5. & $\begin{array}{l}\text { Students use Indonesian language in interacting each } \\
\text { other at school. }\end{array}$ & 0 & 6 & 11 & 28 & 51 \\
\hline
\end{tabular}

$\mathrm{Ctt}: 0=$ not answer; $1=$ never; $2=$ rarely, $3=$ seldom; $4=$ often; $5=$ always

using English. In asking questions, pupils rarely (50\%) use English. About $25 \%$ of the respondents rarely use English in asking questions. None of them always use English in asking questions. Similarly, in answering questions, $42 \%$ of respondents seldom give answers using English and $33 \%$ of them rarely give answers in English. In conclusion, pupils are more comfortable and confident in using foreign language with friends. However, pupils feel less confident when they have to talk to the teacher using foreign language.

These data suggest that various instructional techniques are given by teachers in the classroom. About $33 \%$ of respondents stated that they always use English language in learning and teaching activities, $25 \%$ of them seldom use this language, and $25 \%$ of them rarely use it. Respondents stated that they often use English in asking questions to stu-

Table 5.The Use of English Language in Learning Process in Classroom

\begin{tabular}{lllllll}
\hline No. & Statements & $1(\%)$ & $2(\%)$ & $3(\%)$ & $4(\%)$ & $5(\%)$ \\
\hline 1. & Students communicate each other using English. & 33 & 33 & 8 & 0 & 17 \\
2. & Students ask questions using English. & 0 & 25 & 50 & 17 & 0 \\
3. & Students give answers using English. & 0 & 33 & 42 & 17 & 0 \\
\hline
\end{tabular}

Ctt: $1=$ never; $2=$ rarely, $3=$ seldom;4= often;5= always

\section{Table 6 English Use by Teachers During Teaching Process in Classroom}

\begin{tabular}{lllllll}
\hline No. & Pernyataan & \multicolumn{3}{l}{ Pilihan } & & \\
\cline { 3 - 7 } & & 1 & 2 & 3 & 4 & 5 \\
\hline 1. & Teachers use English as a means of communication & 0 & 25 & 25 & 8 & 33 \\
2. & Teachers use English in asking questions & 0 & 17 & 25 & 33 & 17 \\
3. & Teachers use English in answering questions & 8 & 17 & 33 & 17 & 17 \\
4. & Teachers use English in greeting the students & 0 & 25 & 25 & 25 & 17 \\
\hline
\end{tabular}

Ctt: $1=$ never; $2=$ rarely, $3=$ seldom;4=often;5=always 
dents (33\%), but only $17 \%$ of them often use English when answering student questions. Seen on the basis of this data, respondents in teaching have not maximized their potential. Learning English at elementary level in Bogor has not been effective. According to Purwo (2003:1) effective learning can be done by changing the syllabus, teaching materials, and language activities between teachers and pupils, which require teachers' creativity in interacting with students.

From the data above, it is necessary to revitalize multilingual learning at schools, if the purpose of learning is to improve communication skills. More pupils use Indonesian in communication compare to Sundanese and English language. In order to encourage pupils to use Sundanese language to communicate, Sundanese needs to be used among the pupils, in particular and in general at school.

\section{CONCLUSION}

Based on the objectives of this study, the author's conclusions are as follow.

(1) The effort of West Java Provincial Government to the maintenance of Sundanese language has existed by publishing the Decree of West Java Governor Number 423.5/Kep.674Disdik/2006 on Competence Standards and Basic Competencealso Guidelines for the Preparation of Curriculum Level of Education Unit of SundaneseLanguage and Literature Subject.

(2) Elementary school students in Bogor have negative attitude toward Sundanese language. They are more likely to use Indonesian in conversation at home, at school, and in shopping cen- ters in Bogor. Institutional support for the maintenance of Sundanese language has not been fully visible in every school in Bogor, especially primary schools. This can be seen from the answers given by respondents who $34 \%$ of them agreed on having special day of Sundanese language, but $28 \%$ of them disagreed. In addition, 36\% of respondents did not agree on statement that they have had adequate learning resource facilities. Respondents also expressed their disapproval of special training for Sundanese teachers (45\%). About $43 \%$ of the respondents agreed and $40 \%$ of them strongly agreedon statement that the Sundanese language teachers at elementary schools in Bogor has a very good listening comprehension when others speak Sundanese language. Respondents also expressed disagreement on statement that they are very fluent in speaking Sundanese (stated $26 \%$ of respondents). A total of $21 \%$ and $17 \%$ of the respondents hesitantly answered that they master and are fluently in speaking Sundanese. As many as $36 \%$ of the respondents did not agree to have good scientific writing skills. In contrast, in writing simple things in Sundanese language, $45 \%$ of respondents said that they possess these abilities. Based on this percentage, it appears that teachers' ability on Sundanese language for elementary pupils in Bogor still needs improvement.

(3) Multilingual learning at schools needs to be reviewed. Multilingual learning does not allow pupils to communicate usinglanguages in their 
context. In contrast, one language is used dominantly at schools, namely Indonesian language.

\section{ACKNOWLEDGEMENT}

We would like to thank Litera journal's reviewers for their insightful comments on this paper, as these comments led us to an improvement of the work. Our revision reflects all reviewers 'suggestions and readers' comments.

\section{REFERENCES}

Beardsmore, H.B. (1982). Bilingualism: Basic Principles. Vrije Universiteit Brussel.

Chair, A. \& Leonie, A. (2010). Sosiolinguistik Pengenalan Awal. Jakarta: Rineka Cipta.

Dasripin, P. (2009). Permetahanan bahasa Sunda pada masyarakat di Kabupaten Serang, Provinsi Banten: studi sosiolinguistik. Metalingua: Jurnal Penelitian Bahasa.

http://isjd.pdii.lipi.go.id/index.php/ search.html?act $=$ tampil\&id $=57156$ \&idc $=6$.

Dinas Pendidikan Provinsi Jawa Barat. (2007). Standar Kompetensi dan Kompetensi Dasar Mata Pelajaran Bahasa dan Sastra Sunda. http:// dokumen.tips/documents/2-standar-kompetensi1.html.

Grenoble, L.A., \& Whaley, L.J. (2006). Saving Languages: an Introduction to Language Revitalization. New York: Cambridge University Press.

Jendra, M. I, (2010). Sociolinguistics: The Study of Societies' Languages. Yogyakarta: Graha Ilmu.

Purwo, B.K. (2003). Pengajaran Bahasa Berbasis Kompetensi.Makalh. Semi- nar Nasional dan Temu Alumni dalam 457 Pembelajaran Sastra Berbasis Kompetensi di Sekolah Menengah dalam Rangka Dies XXXIX, 2003 Mei 12.

Saragih A. (2012). Pemertahanan dan Revitalisasi Bahasa Simalungun. http: / / imas-usu.blogspot . com/2012/01/pemertahanan-danrevitalisasi-bahasa.html.

Selvia, A.P. (2014). Permetahan bahasa Sunda dalam Ranah Pendidikan Anak Usia Dini: Kajian Sosiolinguistik di Desa Sarireja, Kecamatan Jalan Cagak, Kabupaten Subang. Jurnal Bahtera Bahasa: Antologi Bahasa dan Sastra Indonesia. 1. http://www. ejournal.upi.edu/index.php/BS_ Antologi_Ind/article/view/461.

[SIL]. (2013). Multilingual Education Programs. http:/ /www. sil.org/ literacy /multi .htm.

Sugiyono. (2014). Metode Penelitian Kuantitatif dan Kualitatif dan $R \& D$. Bandung: Alfabeta, Cetakan ke-20.

UNESCO.(2005). Pendidikan dalam Dunia yang Multibahasa. Jakarta.

Wahya. (2011). Perencanaan Bahasa Sunda ke Depan untuk Mendukung Bahasa Sunda sebagai Media Transformasi Budaya Sunda. Makalah dalam Seminar Internasional Reformasi dan Transformasi Kebudayaan Sunda di Jatinangor, Sumedang pada 9-10 Februari. http://pustaka. unpad.ac.id/wpcontent/uploads/2013/12/Pustaka_Unpad_ Perencanaan_-Bahasa_-Sunda.pdf. pdf.

Wardhaugh, R. (2006). An Introduction to Sociolinguistics. Fifth Edition. Australia: Blackwell Publishing. 